\title{
3 Fiscal interventions in 2020
}

\author{
A comparative analysis of \\ EU states' policies
}

\author{
Michat Wtodarczyk, Rafat Wista, and \\ Monika Bolińska
}

\subsection{Introduction}

More than a decade after the outbreak of the 2008 crisis, the world economy faced again the risk of global instability. The lockdowns, restrictions on spatial mobility of workers and interrupted supply chains resulted in the sharpest drop in the gross domestic product (GDP) since World War II (Kose, Naotaka, 2020).

Like in 2008, some governments intensified their interventionism, increasing again money supply, budget deficits and public debt. The difference between 2008 and 2020 lies in the capability of maintaining long-term macroeconomic stability. The ratio of public debt to GDP in the eurozone amounted to $64.9 \%$ in 2008 . By the end of 2009 , it had risen to $75.7 \%$. The government debt of the eurozone rose until 2014, to reach $86.6 \%$ of GDP. Thereafter, that debt dropped over five years to $77.6 \%$ in 2019 (Trading Economics, 2020).

By the end of Q2 in 2020, the government debt of the eurozone had risen to $95.1 \%$, and in the entire European Union to $87.8 \%$ (Eurostat 2020). That growth was driven principally by extensive fiscal stimulus packages implemented over the period surveyed.

Demertzis et al. (2020) were among the first to assess plans adopted by the European Commission in the spring of 2020 to support the economies of member states: the Coronavirus Response Investment Initiative ${ }^{1}$ (CRII; EUR 25 billion) and EU Solidarity Fund. ${ }^{2}$ Klose and Tillmann (2020) observed, in their panel survey into fiscal responses of the EU member states, a shortterm phenomenon of a rise in return on treasury securities in the states characterized by a high incidence of COVID-19. The return rate rose on the dates of the announcement of subsequent fiscal assistance packages.

In the eurozone, Germany was best prepared for a large unplanned fiscal intervention, as a country that reduced its public debt by 20 percentage

1 https://ec.europa.eu/commission/presscorner/detail/en/IP_20_440.

2 https://ec.europa.eu/regional_policy/en/funding/solidarity-fund/.

DOI: $10.4324 / 9781003211891-3$ 
points in the years 2013-2019 by implementing a balanced budget policy. This made fiscal interventions on a large scale possible in Germany (Busetto, Dufour \& Varotto, 2020). The countries from the High Indebted Euro Countries (HIDC) group, with debts exceeding $100 \%$ of GDP, face the risk of serious macroeconomic instability. The group includes, among others, Italy and Spain (Briceno, Perote, 2020). Italy, despite implementing its fiscal stimulus package, experienced in H1 of 2020 the sharpest drop in GDP in the entire European Union. The concept of government assistance was criticized by experts. They argued that more attention should have been paid to society than to reductions in taxes. A major role was played by the lobby of entrepreneurs who are heavily taxed in Italy (Pietro, Marattin \& Minetti 2020).

Post-pandemic recovery financed by governments will accelerate the pace of growth of the green economy in the European Union. The fiscal stimulus packages reveal that emphasis is put on research and development (R\&D) in advanced power generation sectors, on buildings' energy upgrades and on the prevention of climate change (Hepburn et al., 2020). The International Monetary Fund (IMF) announced that between June and December 2020 the G20 countries implemented fiscal stimulus packages worth USD 9 trillion. This facilitated goal-oriented actions and cooperation (McKibbin, Vines, 2020).

The context outlined in the first and second chapters determines the objective of this chapter, which aims to make a comparative analysis of fiscal responses of the EU member states and of the United Kingdom to the outbreak of the COVID-19 pandemic in the spring of 2020. This study covers the period between January and November 2020. One lockdown or two lockdowns took place in that period in most of the discussed 28 economies. The lockdown measures caused liquidity problems in businesses and entailed insolvency procedures, interruptions in supply chains, suspension of business activity and increases in unemployment. To contain the consequences of the downturn, governments put together subsequent fiscal stimulus packages that were expanded and modified as the pandemic evolved. Separate assistance packages for the eurozone and the member states of the European Union were announced by the European Central Bank and the European Commission. This chapter discusses fiscal packages launched in the 27 member states of the European Union and in the United Kingdom in 2020. The European Union is divided into the eurozone and the group of other states in the below analyses.

\subsection{Eurozone states}

The European Council announced on 21 July 2020 that a special EU recovery fund was established, branded Next Generation EU, with a budget of EUR 750 billion. The fund is financed using debt issue, a digital levy, a carbon border adjustment mechanism and tax on plastics. The funds distributed 
among the member states are divided into subsidies (EUR 390 billion) and loans (EUR 360 billion). All funds will be distributed by the end of 2023, and $70 \%$ of them by the end of 2022 . Next Generation EU, together with the Multiannual Financial Framework 2021-2027, represents the principal instrument of public intervention aimed to reconstruct the EU economies, with total funds amounting to EUR 1.8 trillion (IMF 2020). More than $50 \%$ of funds from the EU budget will be allocated to research and innovation, via Horizon Europe, to energy transition (via the Just Transition Fund) and digitalization (Digital Europe). Thirty percent of funds will be allocated to fighting climate change. Initiatives planned include REACT-EU (supporting employment; EUR 47.5 billion), RescEU (supporting the Civil Protection Mechanism; EUR 1.9 billion) and InvestEU (filling a gap in investments; EUR 5.6 billion) (see Table 3.1 in the appendix).

The Coronavirus Response Investment Initiatives (CRII and CRII+) aim to simplify and make flexible the procedures of using EU funds. They focus on public investments aimed to fight the pandemic, worth EUR 54 billion (European Commission, 2020a).

The Support to Mitigate Unemployment Risks in an Emergency (SURE) instrument, announced on 24 August 2020, is aimed to protect employees and their jobs. The amount of assistance was increased on 16 November from EUR 87.9 billion to EUR 90.3 billion. The funds were raised by issuing social bonds (EUR 17 billion). The money will be made available as loans to $18 \mathrm{EU}$ countries that are particularly affected by the pandemic (European Commission, 2020b) (see Table 3.2 in the appendix).

Table 3.1 Objectives of the Multiannual Financial Framework 2021-2027 and Next Generation EU and their financing

\begin{tabular}{|c|c|c|c|}
\hline Objective & $\begin{array}{l}\text { 2021-2027 } \\
\text { Framework }\end{array}$ & $\begin{array}{l}\text { Next Generation } \\
\text { EU }\end{array}$ & Total \\
\hline $\begin{array}{l}\text { Single market, } \\
\text { innovation and } \\
\text { digital }\end{array}$ & EUR 132.8 billion & EUR 10.6 billion & EUR 143.4 billion \\
\hline $\begin{array}{l}\text { Cohesion, resilience } \\
\text { and values }\end{array}$ & EUR 377.8 billion & EUR 721.9 billion & EUR 1,099.7 billion \\
\hline $\begin{array}{l}\text { Natural resources and } \\
\text { environment }\end{array}$ & EUR 356.4 billion & EUR 17.5 billion & EUR 373.9 billion \\
\hline $\begin{array}{l}\text { Migration and border } \\
\text { management }\end{array}$ & EUR 22.7 billion & - & EUR 22.7 billion \\
\hline Security and defence & EUR 13.2 billion & - & EUR 13.2 billion \\
\hline $\begin{array}{l}\text { Neighborhood and } \\
\text { the world }\end{array}$ & EUR 98.4 billion & - & EUR 98.4 billion \\
\hline $\begin{array}{l}\text { European public } \\
\text { administration }\end{array}$ & EUR 73.1 billion & - & EUR 73.1 billion \\
\hline Total & EUR 1,074.3 billion & EUR 750 billion & EUR 1,824.3 billion \\
\hline
\end{tabular}

Source: European Commission, Recovery plan for Europe, https://ec.europa.eu/info/strategy/ recovery-plan-europe_en (accessed 14 December 2020). 
Considering the currency union, the member states of the European Union will be divided into one group comprising the 19 members of the eurozone, and the second group of other states (including the United Kingdom). The European Stability Mechanism (via Enhanced Conditions Credit Line) will provide the eurozone states with assistance amounting up to $2 \%$ of their GDP (EUR 240 billion in total allocated to expenses on health). The European Investment Bank received a capital injection of EUR 25 billion, allocated to provide small and medium-sized enterprises (SMEs) with assistance in the form of government guarantees (up to EUR 200 billion) (IMF, 2020).

The European Central Bank modified the monetary policy for the eurozone by liquidity injection (improving the liquidity of banks and businesses). Assets worth EUR 120 billion were purchased. The Temporary Pandemic Emergency Purchase Programme (PEPP) was developed, wherein the ECB will purchase securities worth EUR 750 billion in 2020. The requirements for collaterals requested by banks were relaxed and periods for refinancing were extended (ILO, 2020).

\subsubsection{Austria}

The economy of Austria was first locked down between 16 March and 13 April 2020. (The lockdown was introduced again on 3 November.) The Austrian fiscal package, with the value of funds amounting to EUR 38 billion (9.5\% of GDP), was announced on 15 March 2020. The sum of EUR 4 billion was allocated to entities in the healthcare sector, to the preservation of jobs and to supporting companies in which employees contracted COVID-19. The tourism industry and exporters were provided with government guarantees amounting to EUR 9 billion. Corporate Income Tax (CIT) payments were postponed by three months (a cost of EUR 10 billion) and the tax rate was reduced from $25 \%$ to $20 \%$. Hours of work could be reduced by $10 \%$ and pay to $80-90 \%$ of the former level. Households and SMEs were offered a three-month moratorium on loan repayment (IMF, 2020).C

The assistance package was increased to EUR 50 billion in mid-June (13\% of GDP). The package was aimed to support non-profit organizations (EUR 700 million) and research projects (EUR 22 million) and to introduce fiscal relief in the hospitality industry (EUR 500 million). Companies received EUR 2,000 per apprentice to preserve employment. The unemployed received EUR 450 as a one-off allowance, and a children's bonus of EUR 360 per child (also a one-off benefit) (ILO, 2020).

\subsubsection{Belgium}

The lockdown in Belgium was in force between 18 March and 4 May. (The lockdown was introduced again on 2 November.) The value of assistance provided to the economy was set to EUR 17.5 billion (3.9\% of GDP). The value of the total fiscal package, including loans for businesses, amounted 
to EUR 52 billion (12\% of GDP). The funds were allocated to supporting healthcare, people fired due to the pandemic, the self-employed and to postponing the payment of corporate taxes. Employees who lost their jobs received $70 \%$ of their wages (up to EUR 1,450). The assistance measures were targeted at the industries severely affected by the pandemic: taxi companies, cultural, entertainment, hospitality and tourist businesses (KPMG, 2020). Payments of VAT for December 2020 were suspended to improve the liquidity of businesses. The value of donations and gifts made by companies and deductible from income tax was increased. Non-government and volunteer organizations were also supported. A temporary allowance of EUR 126.94 per month for teleworking was introduced. The allowance covered additional costs of heating and electricity (IMF, 2020).

A package of EUR 4.3 billion was allocated to the Flemish Region for investments in digitalization, sustainable growth, education, healthcare, $\mathrm{R} \& \mathrm{D}$ and $5 \mathrm{G}$. Allowances were granted for house reconstruction and repair. Investment deductions were increased for projects implemented between March and December 2020. Deductions of costs incurred on events and catering were increased from $50 \%$ to $100 \%$, to prevent the mass postponement of events until 2021 (ILO, 2020).

\subsubsection{Cyprus}

The economy was locked down between 24 March and 13 April. The value of the fiscal support package amounted to EUR 899 million (4.5\% of GDP), including EUR 100 million allocated to the healthcare sector. Households were provided with assistance, people who lost their jobs received subsidies (up to $70 \%$ ) and the tourism industry was supported (IMF, 2020). The VAT rate was reduced, and its payment was postponed by up to two months. State guarantees were introduced as a measure of domestic assistance provided to businesses and the self-employed, worth in total EUR 2 billion ( $70 \%$ of which was covered by the government and $30 \%$ by banks). SMEs were provided with guarantees or credit financing (EUR 1.7 billion) from the Pan-European Guarantee Fund. Parents employed in the private sector could obtain an allowance for the care of children (aged up to 15 years). Employees who could not work due to contracting the disease received a benefit of EUR 800 monthly (KPMG, 2020).

The central bank provided liquidity injection (EUR 100 million). It also simplified documentation requirements for new short-term loans with favorable interest rates. A moratorium on loan repayment was introduced until the end of December 2020 (ILO, 2020).

\subsubsection{Estonia}

The lockdown in Estonia was in force between 13 March and 1 May. Its fiscal package, worth EUR 2 billion (7\% of GDP), included support provided 
to businesses and employees, and purchases of materials supplied to hospitals. As part of the fiscal package, assistance was provided to the unemployed (EUR 250 million), health insurance premiums were paid (EUR 200 million), liquidity of companies was ensured (EUR 500 million in loans), loans and guarantees were granted (EUR 1 billion), rural areas were given loans (EUR 200 million), the local government received support (EUR 130 million) and investment loans were granted to companies (EUR 50 million). Payments to the pillar II pension funds were suspended and compensation was paid for cancelled cultural and sporting events (EUR 3 million) (ILO, 2020).

The value of short-term treasury notes issued rose by EUR 600 million compared to 2019 (EUR 1 billion in total). A loan amounting to EUR 750 million was obtained from Nordic Investment (repayable over 15 years).

Eesti Pank (the central bank) reduced the systemic risk buffer for the commercial banks from 1\% to $0 \%$. This freed up resources (EUR 110 billion) for loan losses or new loans. Of the central bank's 2019 profits, $75 \%$ (EUR 18.9 million) were allocated to supporting the state budget in the wake of COVID-19 (IMF, 2020).

\subsubsection{Finland}

The government of Finland introduced the lockdown between 16 March and 4 May. An amount of almost EUR 15 billion was allocated to healthcare, public security and border controls. A grant of EUR 1 billion was allocated to research into a vaccine for COVID-19, the development of methods for rapid diagnostics and an expanded knowledge base of the disease. Pension premiums were reduced until the end of 2020 (EUR 1.05 billion) and tax payments were postponed (EUR 4.5 billion). Parental allowance, social assistance and unemployment insurance were expanded (EUR 3 billion). SMEs and the selfemployed obtained access to subsidies (EUR 650 million), and the Finnair airlines received a capital injection (EUR 500 million) (ILO, 2020).

In May 2020, the assistance program was extended by allocating an additional EUR 700 million $(0.3 \%$ of GDP) to share acquisitions in state ownership steering, support provided to restaurant and catering businesses (EUR 123 million) and purchases of vaccines (EUR 16 million). The total increase in government guarantees amounted to EUR 1.68 billion $(0.7 \%$ of GDP). The employment fund received EUR 880 million (from SURE and the European Investment Bank). In June 2020, the assistance package was expanded by adding EUR 1.2 billion (for households and businesses), public investments (EUR 1 billion) and relief in the form of adjusted VAT payments (EUR 750 million) (KPMG, 2020).

The Bank of Finland supported liquidity on the bank market by purchasing short-term corporate securities (EUR 1 billion). This increased Finnish banks' lending capacity by an estimated sum of EUR 52 billion. Maritime transport companies were granted guarantees (EUR 600 million) and exporters were given loans (EUR 14.2 billion) (IMF, 2020). 


\subsubsection{France}

Restrictions were imposed on the French economy between 17 March and 11 May (the second lockdown began on 30 October). A fiscal assistance package, with funds amounting to EUR 135 billion (6\% of GDP), and a package of public guarantees of EUR 327 billion (15\% of GDP) were announced in the spring of 2020. The funds were allocated to health insurance for the sick, an increase in expenses on healthcare and capital injections or nationalizations of companies in difficulty (IMG, 2020). SMEs, micro-enterprises and the self-employed received assistance in the form of suspended rents, social insurance and facility bill payments. Refund of tax credits was accelerated; payment of CIT and VAT was postponed. The government co-financed $60 \%$ of gross wages received by employees. The hardest-hit sectors (automotive and aerospace industries) were provided with green investment support (KPMG, 2020).

In September 2020, the government announced a new fiscal package aimed to support the recovery of the economy (Plan de Relance) with funds amounting to EUR 100 billion. The plan focused on the ecological transformation of the economy, increasing the competitiveness of French firms, and supporting social and territorial cohesion (ILO, 2020).

\subsubsection{Germany}

The lockdown was introduced between 23 March and 20 April (and again as of 2 November). Two fiscal assistance packages were announced, one in March with funds amounting to EUR 156 billion (4.9\% of GDP), and one in June with funds amounting to EUR 130 billion (4\% of GDP). The packages included spending on medical equipment, investments in hospitals, research into a vaccine for COVID-19 and support for green energy and digitalization. SMEs and the self-employed obtained access to grants (EUR 50 billion), short-term subsidies were paid to maintain employment, duration of unemployment insurance and parental leave benefits was expanded and taxes were postponed until the end of 2020. The cultural sector was supported by way of investments projects implemented by cultural institutions (EUR 250 million), protection of SMEs (EUR 480 million), protection of the music, festival and theater sector (EUR 300 million) and digitization of museum collections (Museum 4.0) (EUR 150 million) (ILO, 2020).

VAT rates were reduced (from $19 \%$ to $16 \%$ and from $7 \%$ to $5 \%$ ). The government established Economic Stabilisation Funds (Wirtschaftsstabilisierungsfonds (WSF)) amounting in total to EUR 757 billion (24\% of GDP). Funds support bigger companies and supplement the German development bank's (Kreditanstalt für Wiederaufbau (KfW) special programme.

Local governments supported their economies directly (EUR 141 billion) and by state-level loan guarantees (EUR 70 billion). Exporters were offered 
credit guarantees and subcontractors of German companies received credit collaterals (EUR 30 billion). The self-employed could obtain a one-off support of EUR 5,000 plus EUR 1,000 for employees in geriatric care. A reduction in hours of work by $10 \%$ was made possible, and employee wages continued to be co-financed by the government $(70-75 \%$, depending on the company size). SMEs were offered assistance in employee training (EUR 500 million) (KPMG, 2020).

The Bundesbank supported short-term liquidity (EUR 100 billion), purchased equity in large companies by way of capital contributions (EUR 100 billion) and introduced a three-month moratorium on consumer loans repayable by people affected by the COVID-19 crisis (IMF, 2020).

\subsubsection{Greece}

The first lockdown in Greece was introduced between 24 March and 4 April, and the second began on 3 November. Its fiscal assistance package of EUR 24 billion (14\% of GDP) was financed using domestic and EU funds. Expenditures on healthcare were increased by EUR 88 million (hiring of 3,300 doctors and nurses, procurement of medical supplies, and bonuses to health sector workers) (ILO, 2020).

Suspended employees received EUR 535 monthly. Businesses were supported in the tourism, transport, construction and power generation and distribution industries (EUR 450 million). Businesses that reduced hours of work down to $50 \%$ were offered short-term support amounting to up to $60 \%$ of net pay (through the SYN-ERGASIA program). Businesses affected by the pandemic were offered credit guarantees, interest payment subsidies, a reduction in rents, deferred payment of taxes and of social insurance premiums. The VAT rates on critical products needed for COVID-19 protection, and transport and hospitality services were reduced (KPMG, 2020).

Banks launched a loan moratorium for household and corporate borrowers until the end of 2020. Greece is eligible for the liquidity facility Pandemic Emergency Longer-Term Refinancing Operations (PELTRO) (IMF, 2020).

\subsubsection{Ireland}

The lockdown was introduced between 12 March and $18 \mathrm{May}$, and announced again as of 21 October. The Irish fiscal package of EUR 24.5 billion (7\% of GDP) consisted of direct support (EUR 20.5 billion) and credit guarantees, a stabilization and recovery fund and taxation measures, i.e., warehousing and deferrals. The health sector capacity was enhanced (EUR 2 billion), and the labor market was supported (EUR 11.4 billion). If revenues of a business dropped by more than $30 \%$, the business was offered a subsidy of EUR 203 per employee. Workers who lost their jobs due to the pandemic received EUR 350 per week (until April 2020). Employee wages were subsidized in a maximum proportion of $70 \%$ (up to EUR 410 per week) (ILO, 2020). 


\section{Michat Wtodarczyk et al.}

The Restart Fund (EUR 250 million) made capital contributions in micro and small businesses. SMEs received EUR 2 billion in six-year loans. The government offered guarantees, financed employee training (EUR 200 million) and financed new businesses (EUR 550 million). VAT was reduced from 23 to $21 \%$ for six months. E-commerce received co-financing amounting to EUR 7.6 million (KPMG, 2020).

The Bank of Ireland introduced a moratorium on repayment of mortgage loans (six months) and a moratorium on eviction (six months) and released the countercyclical capital buffer (IMF, 2020).

\subsubsection{Italy}

The first lockdown was introduced between 9 March and 4 April, and the second began on 4 November. The value of the "Cura Italia" emergency package adopted in March amounted to EUR 25 billion (1.6\% of GDP). The funds were allocated to strengthening the healthcare system (EUR 3.2 billion), preserving jobs (EUR 10.3 billion), deferrals of tax and fee payment by businesses affected by the pandemic (EUR 6.4 billion), subsidizing $80 \%$ of wages (up to EUR 1200 monthly paid to people working under contracts of employment and EUR 600 EUR paid to the self-employed). Loan supply was supported (EUR 5.1 billion) and the poor without income received EUR 300 from municipalities (KPMG, 2020).

Additional state guarantees were granted in April (EUR 400 billion; 25\% of GDP). The total value of assistance backed by government guarantees increased to EUR 750 billion, allocated to improve the liquidity of businesses and households. The package was expanded in May by an additional EUR 55 billion (3.5\% of GDP) allocated to support for families (14.5 billion), healthcare (3.3 billion), SMEs (EUR 16 billion). The sum of EUR 25 billion (1.6\% of GDP) was allocated in August to support for employees (EUR 12 billion), income support for families, a suspension of social security contributions and a moratorium on SMEs' debt repayment. Another package of EUR 5.4 billion ( $0.3 \%$ of GDP) was adopted in October to provide relief to the sectors affected by the pandemic and award grants to 460 thousand SMEs and the self-employed (ILO, 2020).

As part of "Cura Italia", the Bank of Italy supported bank lending aimed to provide SMEs with new loans (via Cassa Depositi e Prestiti) and allowed banks to operate with selected ratios below the capital and liquidity requirements. IVASS (the insurance supervision authority) recommended that insurance companies exercise caution in dividend payment (IMF, 2020).

\subsubsection{Latvia}

The economy of Latvia was shut down between 13 March and 12 May. The value of the fiscal package amounted to EUR 3.4 billion $(12 \%$ of GDP). The package included loans and guarantees for businesses affected 
by the pandemic (EUR 1.2 billion) (KPMG, 2020). Support is targeted at the air and transport industry, healthcare, education and infrastructure sectors (EUR 875 million). About 4,500 health care workers received a bonus $(20 \%)$. A wage subsidy of $75 \%$ (up to EUR 700 ) for employees suffering from COVID-19 was introduced. The sum of EUR 50 million was allocated to support large companies (ILO, 2020).

The interest rate on loans obtained by SMEs in the tourism sector was reduced by $50 \%$. The supplementary capital of Finance Development Institution Altum was increased by EUR 100 million to raise its capacity to provide companies with support through loans and guarantees. Altum issued bonds worth EUR 20 million (IMF, 2020).

\subsubsection{Lithuania}

The lockdown was introduced between 16 March and 18 June and again as of 7 November. A fiscal package of EUR 2.5 billion (5\% of GDP) was adopted in March to assist the healthcare system (EUR 500 million), to ensure care for the sick (EUR 250 million), pay wage subsidies for employees (EUR 250 million) and to co-finance climate change investment projects. The government expanded guarantee schemes to EUR 1.3 billion (2.6\% of GDP). A business support fund was established to preserve the liquidity of SMEs with resources amounting to EUR 1 billion (2.1\% of GDP) (IMF, 2020).

The assistance program was expanded in May by EUR 1 billion $(2 \%$ of GDP). Wage subsidies for people returning from unemployment were granted (EUR 380 million), job search allowances paid (EUR 200 million), vocational training financed (EUR 15.6 million).

An investment plan was approved in June, comprising EUR 6.3 billion (13\% of GDP). The sum of EUR 2.2 billion was allocated to new projects and the remaining funds to accelerating the existing ones. The plan included investments in human capital, digital economy, innovation, research, infrastructure, projects addressing climate changes and power generation. Subsidies to wages were increased (to a maximum of $90 \%$ of pay, not more than EUR 607) in SMEs that retained at least $50 \%$ of jobs. Subsidies in large companies could reach a maximum of $70 \%$ (and not more than EUR 910) (ILO, 2020).

\subsubsection{Luxembourg}

The lockdown was in force between 15 March and 4 May, and then mass tests were performed in the population for COVID-19. The EUR 2.3 billion $(3.6 \%$ of GDP) fiscal package was adopted and liquidity support was provided to businesses and the self-employed in the amount of EUR 8.1 billion $(12.8 \%$ of GDP). The funds were allocated to purchases of medical equipment (EUR 194 million), sick leave benefits (EUR 106 million), parental leave benefits (EUR 226 million) and unemployment benefits (EUR 1 billion) (ILO, 2020). 
Micro-enterprises and the self-employed received non-refundable financial assistance in the form of a one-off transfer of EUR 5,000 (EUR 250 million) and guarantees for start-ups (EUR 2.5 billion). The government subsidized up to $80 \%$ of wages. A moratorium on payment of taxes and social insurance premiums was introduced (EUR 4.6 billion) (IMF, 2020).

The fiscal assistance program was expanded in May by EUR 800 million (1.3\% of GDP). The funds were allocated to affected businesses in the hospitality, tourism and sales sectors. The government introduced fiscal incentives to support investments in green recovery (KPMG, 2020).

\subsubsection{Malta}

The partial lockdown was in force between 28 March and 4 May. A fiscal package was adopted, with funds amounting to EUR 520 million $(4 \%$ of GDP), to support the healthcare sector (EUR 130 million), businesses and households (subsidies to rents, benefits, a moratorium on loan repayment). Subsidies to employee wages amounted to a maximum of EUR 800 monthly. A direct grants scheme was approved to support investment in research and development related to the coronavirus outbreak (EUR 5.3 million) (KPMG, 2020).

The assistance program was expanded in June by EUR 900 million (7\% of GDP). The funds were allocated to infrastructure investments (EUR 400 million), a moratorium on tax payments (200 million), tourist cash vouchers, reduced fuel prices and a tax refund for workers. Teleworkers received a one-off benefit (EUR 400) (ILO, 2020).

The Malta Development Bank established a guarantee fund of EUR 350 million $(2.7 \%$ of GDP) available to businesses affected by the pandemic. The value of guaranteed loans reached EUR 780 million (6\% of GDP). A six-month moratorium for borrowers was introduced (IMF, 2020).

\subsubsection{The Netherlands}

The lockdown was introduced between 15 March and 11 May and announced again as of 14 October. Two fiscal packages were approved (in March and in May) with funds amounting to EUR 33 billion (4.2\% of GDP). The government compensated up to $90 \%$ of labor costs in businesses that lost more than $20 \%$ of income, and also paid compensations in affected sectors (hospitality, travel, agriculture, culture). Unemployment benefits were raised and subsidies for SMEs, the self-employed and start-ups were introduced (ILO, 2020).

Deferred taxes payable by businesses amounted to EUR 16.6 billion (2.1\% of GDP). A program of public guarantees for SMEs to the sum of EUR 61 billion (7.8\% of GDP) was adopted. Expanding sectors were offered support of labor mobility and training programmes (IMF, 2020). 


\subsubsection{Portugal}

Portugal introduced the lockdown between 19 March and 17 April. A fiscal package was adopted to support the economy (EUR 5.2 billion); the government granted credit guarantees (EUR 3 billion) and deferred payment of taxes and social insurance premiums (EUR 1 billion). The assistance program included additional expenses on healthcare, digitalization of education (EUR 538 million), digitalization of public finance (EUR 1.65 billion), incentives for people resuming business activity (EUR 1.3 billion) and benefits for people forced to stay home to care for children. Government subsidies to wages amounted to a maximum of $70 \%$ (KPMG, 2020).

The government offered SMEs credit guarantees worth EUR 13 billion (6.8\% of GDP) and loans (EUR 200 million). The support package targeted at small and micro-enterprises was expanded in November by subsidies (EUR 0.8 billion) and credit guarantees (EUR 0.8 billion), to strengthen businesses affected by the pandemic (ILO, 2020).

Banco de Portugal relaxed its macroprudential measures for consumer credit and postponed loan repayment (owed by businesses and households) until September 2020, rescheduled on-site inspections and the stress test exercise. Lines of credit were granted to restaurants (EUR 600 million), tourist agencies (EUR 200 million), the hospitality industry (EUR 900 million), and the garment industry (EUR 1.3 billion) (IMF, 2020).

\subsubsection{Slovakia}

The economy was shut down between 16 March and 22 April. The government performed national tests for COVID-19. Unemployment benefits, sickness and nursing benefits were raised, the labor market was supported with EUR 197 million, the government introduced subsidies to rents and compensations for businesses and the self-employed (including deferrals of social insurance premiums). Businesses were offered subsidies amounting to a maximum of $80 \%$ of employee wages, depending on the decrease in their revenues (EUR 180 to 540) (KPMG, 2020). The poor without income were offered a one-off benefit of EUR 210 during the state of emergency. Quarantined people were eligible for 55\% of their wages paid by the government. SMEs and large companies were offered government guarantees amounting to EUR 4 billion (4.3\% of GDP) (ILO, 2020).

The Bank of Slovakia permitted banks to temporarily operate below the defined level of capital, temporarily exempted banks from full compliance with the LCR (liquidity coverage ratio) (IMF, 2020).

\subsubsection{Slovenia}

The lockdown was introduced between 20 March and 15 May and announced again as of 16 October. The authorities adopted a fiscal package 
of EUR 1 billion (2.2\% of GDP) in March; the package included support for entrepreneurs, subsidies for suspended workers (EUR 50 million), a oneoff transfer to pensioners and students, a reduction in prices for electricity by one-third, deferrals of tax and social insurance premium payments. The government also made available its guarantees amounting to EUR 600 million (ILO, 2020).

The assistance program was expanded in April by EUR 5 billion of credit lines, guarantees and subsidies to wages. The additional sum of EUR 1 billion was allocated in May to vouchers for tourism (EUR 200 per adult and EUR 50 per child) and liquidity loans for businesses. The government assistance program was expanded in November by EUR 1 billion used to subsidize wages (up to $80 \%$ ), exempt renters from rent payment and pay compensation to businesses that were losing revenue (KPMG, 2020).

The Bank of Slovenia reduced the maximum level of permitted bank account fees and allowed banks to temporarily exclude income declines caused by the pandemic when calculating creditworthiness and to defer bank loan repayments for up to 12 months (IMF, 2020).

\subsubsection{Spain}

The lockdown was in force between 14 March and 9 May. The adopted fiscal package of EUR 42 billion (3.8\% of GDP) was used to assist healthcare (EUR 1.4 billion), medical services (EUR 2.9 billion), pay unemployment benefits (EUR 18 billion), sick benefits (EUR 1.4 billion), support industry (EUR 375 million) and education (EUR 40 million). The government subsidized up to $70 \%$ of wages received by people affected by COVID- 19 . Capital contributions were made to the State Housing Plan 2018-21 (EUR 450 million). People in need had access to funds (EUR 300 million) and children were offered meals (EUR 25 million). A minimum income scheme was implemented (EUR 3 billion). The scheme included 850,000 families (2.3 million people). The extent of poverty was to be reduced by that measure by $80 \%$. The lowest rate amounted to EUR 462 per adult and EUR 139 per child. A family could receive a maximum of EUR 1,015 monthly (ILO, 2020).

The self-employed who suspended their business activity received assistance (EUR 5.5 billion). A group was exempted from payment of social insurance premiums (EUR 2.7 billion). Businesses were offered a moratorium on tax and social insurance premium payments (EUR 533 million). Tax on digital publications was reduced from $21 \%$ to $4 \%$ (EUR 5 million). Transitioning to low-emission vehicles was subsidized (MOVE II; EUR 250 million) (KPMG, 2020).

The Bank of Spain announced a moratorium for mortgage borrowers for three months, guarantees for exporters (EUR 2 billion), guarantees and 
loans for businesses (EUR 100 billion) and a rescue fund to support strategic business (EUR 10 billion). Instituto de Crédito Oficial launched credit guarantees to support investments in digitalization and sustainable growth (EUR 40 billion) (IMF, 2020).

\subsection{States with separate currencies}

\subsubsection{Bulgaria}

The lockdown in Bulgaria was in force between 13 March and 15 June. An assistance package was adopted in that country (BGN 4.5 billion). The value of government guarantees was increased, the VAT rate was reduced (from $20 \%$ to $9 \%$ ), the government introduced subsidies to wages in the industries affected by the pandemic (up to $60 \%$ of pay), paid doctors and nurses a bonus of BGN 1,000 and distributed vouchers for tourism (BGN 210 per person). The operational program "Human Resources Development" was launched to assist people over 65 (BGN 45 million) (ILO, 2020).

The government provided assistance to SMEs and large companies that lost more than $20 \%$ of their revenues. Businesses in the tourism, healthcare and transport sectors received BGN 290 monthly per job retained (KPMG, 2020).

The central bank of Bulgaria implemented liquidity support measures for banks to the value of BGN 13.7 billion (6\% of GDP), cancelled the increase in the countercyclical capital buffer and reduced foreign exposures of commercial banks (IMF, 2020).

\subsubsection{Croatia}

The lockdown was in force between 18 March and 27 April. An assistance package was adopted, with the value of HRK 30 billion. Subsidies to wages were introduced to preserve jobs. Croatian micro-businesses could obtain support for $20 \%$ of their employees. Up to $10 \%$ of employees were supported in medium-sized enterprises. Grants amounted to HRK 2,000 to 4,000 monthly per employee, depending on the extent of income lost. Local governments were given low-interest loans. EU funds have been partly reallocated to micro-loans (ILO, 2020).

The Bank of Croatia supported liquidity of domestic banks. Short-term notes were issued for HRK 3.8 billion, the reserve requirement ratio was reduced (from $12 \%$ to $9 \%$ ), a three-month moratorium on obligations to banks was introduced and securities were purchased in the secondary market (HRK 17.9 billion). The Croatian Bank for Reconstruction and Development launched export guarantees and liquidity loans. In October 
2020, the European Investment Bank (EIB) approved a financial package (EUR 200 billion) for faster recovery of Croatian SMEs (IMF, 2020).

\subsubsection{Czech Republic}

The lockdown was introduced between 13 March and 12 April, and announced again as of 3 November. A fiscal package was adopted with funds amounting to CZK 273 billion (EUR 10.4 billion; 4.9\% of GDP). The government subsidized $80 \%$ of wages paid to quarantined employees until the end of 2020 (up to CZK 39,000), 60\% of wages paid to people with reduced hours of work (up to CZK 29,000) and 100\% of wages paid to people who lost their jobs due to the lockdown. The VAT rate was reduced (from 15 to $10 \%)$ in hotels, in the cultural and sports sector, and subsidies were paid (CZK 2 billion). One-off support for pensioners (CZK 5000) and support for welfare workers (CZK 16.6 billion) were announced (ILO, 2020).

During the second phase of lockdown, affected sectors received assistance (CZK 7.7 billion), SMEs and the self-employed obtained grants (CZK 500 daily), and state subsidies were introduced (CZK 500 billion; 9\% of GDP). Rural areas were supported (CZK 3.3 billion) to stimulate food production (KPMG, 2020).

The Czech National Bank reduced the policy rate (down to $0.25 \%$ ), decreased the countercyclical capital buffer rate (down to $0.5 \%$ ) and announced a moratorium on loan repayment (for six months) (IMF, 2020).

\subsubsection{Denmark}

The lockdown was in force between 13 March and 13 April. The fiscal assistance package (DKK 131 billion; 5.7\% of GDP) was allocated to supporting businesses, the medical sector and the self-employed. Payment of taxes was deferred and government guarantees were announced. The value of another package amounted to $5.1 \%$ of GDP (KPMG, 2020).

Businesses affected by the pandemic were reimbursed for $25-80 \%$ of their fixed costs. The self-employed who lost more than $30 \%$ of their revenues were reimbursed for up to $90 \%$ of lost revenues. The government introduced subsidies to employee wages (up to $75 \%$; not more than DKK 30,000 monthly per employee). Monthly support per person in start-ups amounted to a maximum of DKK 23,000. The Scandinavian airlines were subsidized (DKK 6 billion) (ILO, 2020).

The Bank of Denmark raised the policy rate to $-0.6 \%$ (from $-0.75 \%$ ), opened a line of credit for banks and announced government guarantees covering $70 \%$ of corporate debt caused by the pandemic. Standing swap lines with ECB (EUR 24 billion) and FED (USD 30 billion) were activated (IMF, 2020). 


\subsubsection{Hungary}

The lockdown was in force between 28 March and 16 June. The adopted assistance package of HUF 1.34 billion ( $3.2 \%$ of GDP) was used to alleviate the fiscal burden on businesses (800,000 SMEs), support the tourism sector (HUF 600 billion) and employees of the healthcare sector (HUF 500,000) and introduce subsidies to wages of fired and suspended workers (up to $70 \%$ of average pay). An Anti-Epidemic Protection Fund and an economy protection fund were established to protect jobs (HUF 450 billion). Exporters received subsidies from the Eximbank state bank (HUF 800,000). The MFB bank offered a package of financial support instruments for companies (HUF 1.49 billion): three loan products, two guarantee products and four capital products.

The purchase of bank bonds issued during the crisis (HUF 150 billion) was announced in May when also government guarantees and low-interest loans for SMEs were expanded (ILO, 2020).

The central bank (MNB) supported the liquidity of businesses by regular swaps, the expansion of eligible collateral, long-term lines of credit. The base rate was reduced to $0.6 \%$. The MNB purchased government bonds (50\% of the issued value) and corporate bonds (purchases for HUF 793 billion out of 2 trillion planned) (IMF, 2020).

\subsubsection{Poland}

The lockdown was in force between 13 March and 20 April. The initial assistance program consisted of a fiscal package of PLN 116 billion $(5.2 \%$ of GDP), credit guarantees and micro-loans for businesses amounting to PLN 74 billion (3.3\% of GDP). The assistance program was expanded in May by PLN 212 billion (9\% of GDP). The healthcare sector was supported (PLN 7.5 billion), the unemployment benefit was raised by 39\%, a solidarity benefit was paid to people fired due to the pandemic and a voucher for tourism was introduced (PLN 500 per child). The government subsidized $40 \%$ of employee wages (50-90\% of the minimum wage) in enterprises that recognized a drop in revenues exceeding 30\% (ILO, 2020).

The Polish Development Fund gave loans (PLN 100 billion) to support liquidity of SMEs that were exempted from repaying $70 \%$ of their resultant debt. Also, a three-month moratorium on payment of taxes, loan instalments and social insurance premiums was announced. The Governmental Fund for Local Investments was established (PLN 12 billion) to support investments with a value exceeding PLN 400 thousand. Companies managing airports received support amounting to PLN 1 billion. Measures of protection against hostile takeovers were adopted (to protect businesses that achieved revenues exceeding EUR 10 million) (KPMG, 2020). 


\section{Michat Wtodarczyk et al.}

The central bank (NBP) reduced the policy rate (to $0.1 \%$ ) and required reserve ratio (from 3.5 to $0.5 \%$ ) and repealed the systemic risk buffer $(3 \%$ ). The NBP also purchased treasury securities for PLN 105.5 billion $4.6 \%$ of GDP) (IMF, 2020).

\subsubsection{Romania}

The lockdown was in force between 25 March and 15 May. The state assistance program consisted of a fiscal package (RON 20 billion), grants provided to SMEs for digitalization (RON 15 billion) and government guarantees (RON 15 billion). The government paid people fired due to the pandemic up to $75 \%$ of average wage. The expenses on pensions were increased by $14 \%$ while the hours of work were reduced to 4 days a week (ILO, 2020).

The businesses affected by the lockdown could receive support for procurement of work equipment (RON 1.5 billion), discounts in paying corporate income tax, deferral in payment of tax on real property and suspension of enforced debt collection (KPMG, 2020).

The central bank reduced the policy rate (to $1.5 \%$ ) and requested commercial banks to announce a moratorium on loan repayment by businesses and households. Treasury notes were purchased for RON 39.5 billion (IMF, 2020).

\subsubsection{Sweden}

Sweden is the only EU country that did not implement any lockdown measures. Merely some restrictions were imposed and recommendations given. Fiscal assistance of SEK 803 billion (16\% of GDP) included subsidies paid to the affected sectors (sport, education, culture, media), raised unemployment benefits and grants received by municipalities (SEK 5.5 billion). The government financed up to $75 \%$ of wages while employers added $15 \%$ (employees received in total up to $90 \%$ of their wages). People from the risk group received compensations (SEK 257 billion) (ILO, 2020).

SMEs were offered loans, deferred tax payments (SEK 13 billion) and capital injections (SEK 3 billion). The self-employed also received support (SEK 5 billion). Export credits (SEK 200 billion) and government guarantees (SEK 500 billion; 9.6\% of GDP) were made available. Infrastructure investments were announced, regional public transport companies and regional airports were provided with support. The state also provided the SAS airlines with capital injections. The European Investment Bank allocated an additional SEK 250 billion to Swedish businesses. Subsequent fiscal packages were planned (SEK 105 billion in 2021 and SEK 85 billion in 2022) (KPMG, 2020). 
The Bank of Sweden (Riksbank) reduced interest rates on loans and facilitated lending to businesses (up to SEK 500 billion). The Bank eased countercyclical capital buffer and purchased securities (SEK 500 billion). A swap facility was established between the Riksbank and Federal Reserve (FED)(IMF, 2020).

\subsubsection{United Kingdom}

The lockdown was introduced between 23 March and 13 May, and announced again as of 5 November. The assistance package included additional funding for the National Health Service and public services (GBP 48.5 billion), protection of jobs (GBP 1,000 per retained job), a quarantine allowance (GBP 130) and expenditures on improved energy efficiency. Government subsidies to wages dropped from $80 \%$ (GBP 2,500) to $60 \%$ (GBP 1,875) of the original wage. Employers financed at least $20 \%$ (up to $80 \%$ of the initial wage) (ILO, 2020).

Businesses obtained support amounting in total to GBP 29 billion, a sixmonth deferral of the payment of income tax, VAT and social insurance contributions, subsidies to innovation (GBP 1 billion) and credit guarantees (up to GBP 5 million). The VAT rate on tourist services and accommodation was temporarily reduced (from $20 \%$ to $5 \%$ ) (KPMG, 2020).

The Bank of England reduced the bank rate (to $0.1 \%$ ), offered loans and guarantees (GBP 330 billion; 15\% of GDP) and reduced the countercyclical buffer rate (to $0 \%$ ). Treasury securities (GBP 450 billion) and corporate securities (GBP 200 billion) were purchased (IMF, 2020).

\subsection{Conclusions}

An analysis of the fiscal and monetary responses of the European Union member states and the United Kingdom to the COVID-19 pandemic (until December 2020) leads to the following conclusions.

First, all countries covered by this study (except Sweden) implemented certain lockdown measures (a state of emergency with limited mobility of employees, closed border checkpoints, a ban on certain business activities). Those lockdown measures were in force for periods between 20 and 94 days. Restrictions imposed on social functions and economic activities caused a reduction in GDP of the analyzed economies by a total of EUR 188.7 billion, i.e. $-4.5 \%$ of EU GDP (between Q4 of 2019 and Q3 of 2020). The sharpest drops were observed in Croatia $(-12 \%)$ and Greece $(-11 \%)$. The most dramatic nominal falls were observed in Great Britain (EUR 53 billion) and Germany (EUR 33.6 billion). The "freeze" of the economy caused an increase in unemployment rates in the countries surveyed from 
$5.8 \%$ to $7.2 \%$ on average. The most dramatic increase was observed in Lithuania (by 4.4 percentage points) and in Estonia (by 3.4 percentage points.)

Second, emergency programs were launched and a record-breaking fund dubbed Next Generation EU (EUR 1.8 trillion) was established at the European Union level. A series of programmes were developed, aimed to stimulate growth in the member states, promote employment and innovation, and support implementation of the European Green Deal. The SURE instrument, designed for the preservation of employment, will disburse to the most affected EU countries the amount of EUR 90.3 billion. Special lending, guarantee and subsidy schemes for businesses were launched in the eurozone (up to EUR 200 billion), and the ECB purchased assets worth EUR 750 billion in 2020.

Third, the methods employed to support various European economies were consistent. Subsidies to employee wages and training were paid, tax rates reduced, and temporary moratoriums introduced (on taxes, loan repayment, social insurance contributions) with the aim of preserving employment. Businesses were supported by subsidies, allowances, co-financing of rents and credit guarantees (the measures were focused on SMEs in the sectors most affected by the pandemic, such as tourist, hospitality, cultural and transport businesses). In the area of monetary instruments, interest rates were reduced and treasury and corporate securities purchased which resulted in an increase in money supply.

Fourth, all support packages imposed heavy financial burdens on the budgets of the states covered by the survey. The total budget deficits amounted in Q2 of 2020 to EUR 473.98 billion. Consequently, government debt rose in the surveyed economies from $80 \%$ to $90.6 \%$ of GDP on average. The most dramatic increase was observed in Cyprus (by 19.2 percentage points), Belgium (by 16.6 percentage points) and France (by 16 percentage points). The states that recognized the greatest values of debt in the European Union (government debt exceeding 100\% of GDP) were Greece $(187.4 \%)$, Italy (149.4\%), Portugal (126.1\%), Belgium $(115.3 \%)$, France $(114.1 \%)$, Cyprus $(113.2 \%)$ and Spain $(110 \%)$.

Fifth, proportions of package values in GDP significantly vary. Fiscal packages (excluding guarantees) that exceeded $10 \%$ of GDP were adopted in Sweden (16\%), Greece (14\%), Austria (13\%), Latvia (12\%), Belgium $(12 \%)$, France $(10.4 \%)$. Fiscal packages with values below $4 \%$ of GDP were announced in Bulgaria (1.9\%), Slovakia $(2.7 \%)$, Portugal $(2.7 \%)$, Hungary $(3.2 \%)$ and Spain $(3.8 \%)$. 


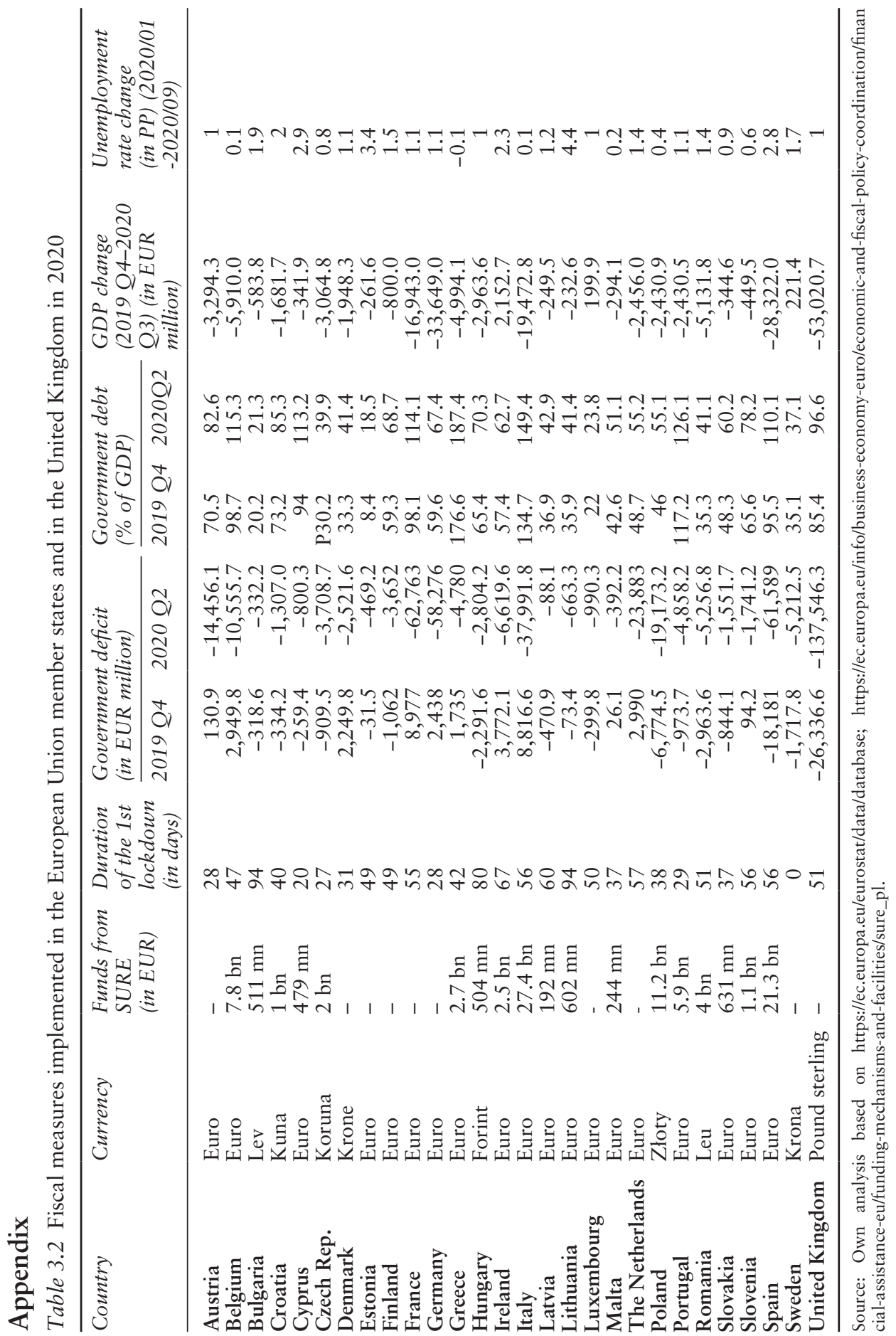




\section{References}

Briceno, H. R., Perote, J. (2020). Determinants of the public debt in the Eurozone and its sustainability amid the Covid-19 pandemic. Sustainability, 12(16), 6456.

Busetto, F., Dufour, A., Varotto, S. (2020). COVID-19 and fiscal policy in the Euro Area. In Billio, M., Varotto, S. (eds.) A new world post COVID-19 lessons for business, the finance industry and policy makers. Edizioni Ca'Foscari, Venice, Italy.

Demertzis, M., Sapis A., Tagliapietra, S., Wolff, G.B (2020). An effective economic response to the Coronavirus in Europe. Policy Contribution, Breugel, 6.

Dynus, M. (2007). Polityka fiskalna. Towarzystwo Naukowe Organizacji I Kierowania Stowarzyszenie Wyższej Użyteczności. Dom Organizatora, Toruń, 1.

Działo, J. (2012). Dlaczego trudno jest prowadzić “dobrą" politykę fiskalną? Gospodarka Narodowa, 1-2(245-246), 25-40.

Eurostat (2020). Second quarter of 2020 compared with first quarter of 2020 Government debt up to $95.1 \%$ of GDP in euro area Up to $87.8 \%$ of GDP in EU [website]. https://ec.europa.eu/eurostat/documents/2995521/11442886/222102020-BP-EN.pdf/a21ffbf8-09c9-b520-8fa9-6e804146bf0f (accessed December 8, 2020).

Fedorowicz, Z. (1998). Polityka fiskalna. Wydawnictwo Wyższej Szkoły Bankowej w Poznaniu, Poznań.

Hepburn, C., O’Callaghan, B., Stern, N., Stiglitz, J., Zenghelis, D. (2020). Will COVID-19 fiscal recovery packages accelerate or retard progress on climate change? Oxford Review of Economic Policy, 36(S1), 359-381.

International Labour Organization (ILO) (2020). Country policy responses, [website]. https:/www.ilo.org/global/topics/coronavirus/regional-country/ country-responses/lang--en/index.htm\#UN (accessed December 14, 2020).

International Monetary Fund (IMF) (2020). Policy responses to COVID-19, [website]. https://www.imf.org/en/Topics/imf-and-covid19/Policy-Responses-toCOVID-19\#E (accessed December 14, 2020).

Klose, J., Tillmann, P. (2020). COVID-19 and financial markets: A panel analysis for European Countries, joint discussion paper series in economics, 25-2020. Philipps-Universität Marburg, Faculty of Business Administration and Economics, Department of Economics. https://www.uni-marburg.de/fb02/makro/forschung/ magkspapers/paper_2020/25-2020_klose.pdf (accessed December 12, 2020).

Komisja Europejska (2020a). Plan odbudowy dla Europy [website]. https://ec.europa. eu/info/strategy/recovery-plan-europe_pl\#finansowanie-dugoterminowego-bud etu-ue-i-nextgenerationeu (accessed December 14, 2020).

Komisja Europejska (2020b). Instrument SURE [website]. https://ec.europa.eu/ info/business-economy-euro/economic-and-fiscal-policy-coordination/financialassistance-eu/funding-mechanisms-and-facilities/sure_pl (accessed December 14, 2020).

Kose, A., Naotaka, S. (2020). WorldBank blog [web blog] Understanding the depth of the 2020 global recession in 5 charts. https://blogs.worldbank.org/opendata/ understanding-depth-2020-global-recession-5-charts (accessed December 8, 2020).

KPMG (2020). Government Response - Global landscape. An overview of government and institution measures around the world in response to COVID19 [website]. https://home.kpmg/xx/en/home/insights/2020/04/governmentresponse-global-landscape.html (accessed December 14, 2020). 
McKibbin, W., Vines, D. (2020). Global macroeconomic cooperation in response to the COVID-19 pandemic: A roadmap for the G20 and the IMF. Oxford Review of Economic Policy, 36(S1), 297-337.

Pietro, M., Marattin, L., Minetti, R. (2020). Fiscal policies amid a pandemic: The response of Italy to the COVID-19 crisis. National Tax Journal, 73(3), 927-950.

Trading Economics. Euro area government debt to GDP [website]. https:// tradingeconomics.com/euro-area/government-debt-to-gdp (accessed December 08, 2020). 